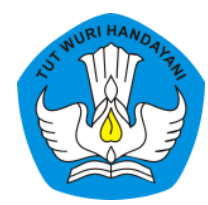

Page: 165-176

\title{
PENINGKATAN HASIL BELAJAR TIK MELALUI MODEL PEMBELAJARAN THINK-PAIR-SHARE DENGAN CAMTASIA STUDIO PADA SISWA
}

\author{
Wardoyo \\ Sekolah Menengah Pertama Negeri 3 Dongko, Jawa Timur, Indonesia \\ Contributor Email: wardoyoskom@gmail.com
}

Received: Feb 3, 2021

Accepted: Mar 10, 2021

Published: Mar 30, 2021

Article Url: https://ojsdikdas.kemdikbud.go.id/index.php/didaktika/article/view/234

\begin{abstract}
This study aims to determine objectively about the improvement of learning outcomes in Information and Communication Technology (ICT) through the Think-Pair-Share (TPS) model with Camtasia Studio in class VIII junior high school students. The method used in this research is the classroom action research method according to $M c$ Taggart, $R$ and Kemmis, $S$ which consists of 4 stages, namely planning, action, observation and reflection. The procedure is carried out in the form of a cycle that lasts two cycles with each cycle consisting of 2 meetings. Data presentation was carried out by means of quantitative analysis which was measured based on a written test conducted at the end of each cycle. The results showed that quantitatively there was an increase in ICT learning outcomes after the application of the Think-PairShare (TPS) model with Camtasia Studio, namely the increase in: (a) The average from cycle $1=83.91$ to $=89.35$ in the cycle 2, or there is an increase of 5.43 values; (b) The number of students who scored $\geq 75(K K M=75)$ : from cycle $1=78.26 \%$ to $100 \%$ in cycle 2, or an increase of $21.74 \%$. From the analysis it can be concluded that learning with the Think Pair Share model with Camtasia Studio can improve ICT learning outcomes for class class VIII A students in SMP Negeri 3 Dongko.
\end{abstract}

Keywords: Learning Outcomes; ICT; Think Pair Share; Camtasia Studio. 


\begin{abstract}
Abstrak
Penelitian ini bertujuan untuk mengetahui secara objektif tentang peningkatan hasil belajar Teknologi Informasi dan Komunikasi (TIK) melalui model Think-Pair-Share (TPS) dengan Camtasia Studio pada siswa SMP kelas VIII. Metode yang digunakan dalam penelitian ini adalah metode penelitian tindakan kelas menurut Mc Taggart, $R$ dan Kemmis, $S$ yang terdiri dari 4 tahap, yaitu perencanaan, Tindakan, observasi dan refleksi. Prosedur yang dilaksanakan berbentuk siklus yang berlangsung dua siklus dengan setiap siklusnya terdiri dari 2 pertemuan. Penyajian data dilakukan secara analisis kuantitatif yang diukur berdasarkan tes tertulis yang dilakukan setiap akhir siklus. Hasil penelitian menunjukkan bahwa secara kuantitatif terjadi peningkatan hasil belajar TIK setelah diterapkannya model Think-Pair-Share (TPS) dengan Camtasia Studio, yaitu terjadinya peningkatan: (a) Ratarata dari siklus $1=83,91$ menjadi $=89,35$ pada siklus 2, atau terjadi kenaikan 5,43 nilai; (b) Jumlah siswa yang bernilai $\geq 75$ (KKM = 75): dari siklus $1=78,26 \%$ menjadi $100 \%$ pada siklus 2, atau naik 21,74\%. Dari analisis dapat disimpulkan bahwa pembelajaran dengan model Think Pair Share dengan Camtasia Studio dapat meningkatkan hasil belajar TIK siswa kelas VIII A di Sekolah Menengah Pertama (SMP) Negeri 3 Dongko.
\end{abstract}

Kata Kunci: Hasil Belajar; TIK; Think Pair Share; Camtasia Studio.

\title{
A. Pendahuluan
}

Belajar adalah suatu proses yang ditandai adanya perubahan pada diri seseorang. Perubahan sebagai proses belajar dapat ditunjukkan dalam berbagai bentuk seperti berubahnya pengetahuan, pemahaman sikap, tingkah laku, keterampilan, kecakapan dan kemampuannya serta berubahnya aspek-aspek lain yang ada pada individu yang belajar. Pembelajaran mata pelajaran TIK di SMP diberikan dengan tujuan untuk membekali siswa akan konsep-konsep penting dalam penguasaan teknologi informasi (iInformation teknologi). Pada satuan pendidikan SMP, TIK memuat konsep dan kajian materi pengenalan media informasi, perangkat lunak dan keras komputer, program untuk aplikasi kantor sampai dengan penguasaan dan aplikasi jaringan local dan global (internet).

Berdasarkan hasil observasi yang dilaksanakan di Kelas VIII A SMP Negeri 3 Dongko, banyak ditemui siswa kurang begitu paham terhadap materi pelajaran yang telah diajarkan guru di kelas. Hal ini dikarenakan hambatan komunikasi yang berjalan kurang begitu baik 
terjalin antara guru dan siswa, saat guru menjelaskan materi membuat dokumen baru, pengaturan lebar kolom dan tinggi baris, serta meletakan data dan mengatur tampilan border, banyak siswa yang tidak memperhatikan penjelasan guru, ada yang melamun, bertopang dagu, berbisik-bisik dengan temannya dan lain sebagainya. Kurangnya sarana dan prasarana penunjang untuk praktikum siswa menambah permasalahan ini semakin nyata, idealnya setiap siswa menggunakan komputer sendiri-sendiri, kenyataannya komputer digunakan untuk berdua atau bertiga dengan temannya. Selain itu dari studi awal diketahui bahwa siswa kurang aktif dan kurang antusias dalam mengikuti pelajaran, karena metode pembelajaran yang digunakan guru kurang menarik bagi siswa. Guru tidak menggunakan media sama sekali dalam mengajar, sedangkan untuk membuat pembelajaran menarik dan menyenangkan ada dua aspek yang menonjol yang harus diterapkan guru, yaitu metode mengajar dan media pembelajaran sebagai alat bantu mengajar (Sudjana \& Rivai, 2009). Hal tersebut memberikan dampak negatif terhadap hasil belajar siswa, terutamanya hasil belajar mata pelajaran TIK pada kompetensi dasar perangkat lunak pengolah angka sederhana. Hal lain memperkuat argumen diatas pada saat dilakukan ulangan harian dengan materi indikator membuat dokumen baru, pengaturan lebar kolom dan tinggi baris, serta meletakan data dan mengatur tampilan border dengan $\mathrm{KKM}=75$ diperoleh hasil yang sangat mengecewakan, yaitu $52,17 \%$ atau 12 siswa tuntas dan $47,83 \%$ atau 11 siswa tidak tuntas.

Berdasarkan sebab-sebab tersebut peneliti memfokuskan pada metode mengajar yang masih bersifat konvensional. Salah satu cara yang dapat ditempuh adalah dengan pengembangan metode mengajar agar tidak terpaku pada metode mengajar konvensional. Oleh karena itu metode konvensional dalam pengajaran TIK harus diubah. Hal ini dilakukan agar siswa tidak lagi merasa bosan dalam mengikuti pelajaran. Sebaliknya dengan metode baru siswa diharapkan lebih aktif tidak 
lagi hanya sekedar menerima informasi atau diceramahi guru, tetapi bisa memberikan informasi kepada teman-temannya.

Salah satu metode mengajar yang dapat diterapkan oleh guru untuk mengatasi permasalahan di atas dan mampu menciptakan suasana belajar yang aktif dan tidak membosankan adalah model pembelajaran kooperatif Think Pair-Share dengan Camtasia Studio. Model Think Pair Share merupakan salah satu pembelajaran kooperatif yang memungkinkan siswa belajar sendiri dan bekerja sama dengan siswa lain dalam kelompok (Huda, 2011: 136). Model pembelajaran kooperatif Think-Pair-Share memberikan siswa waktu untuk berpikir, menjawab, merespon dan membantu satu sama lain. Jadi selama proses belajar mengajar diharapkan semua siswa aktif karena pada akhirnya nanti masing-masing siswa secara berpasangan harus membagikan hasil diskusinya di depan kelas kepada teman-teman lainnya. Model ThinkPair-Share dikembangkan untuk meningkatkan penguasaan isi akademis siswa terhadap materi yang diajarkan. "Think-pair-share and Numbered heads together, described here, are two examples of structures teachers can use to teach academic content or to check on student understanding of particular content" (Arends, 1997: 122).

Peningkatan penguasaan akademis siswa terhadap materi pelajaran dilalui dengan tiga proses tahapan yaitu melalui proses thinking (berpikir) siswa diajak untuk merespon, berpikir dan mencari jawaban atas pertanyaan guru, melalui proses pairing (berpasangan) siswa diajak untuk bekerjasama dan saling membantu dalam kelompok kecil untuk bersama-sama menemukan jawaban yang paling tepat atas pertanyaan guru. Selanjutnya tahap sharing (berbagi), siswa diminta membagi hasil diskusi kepada teman kelompoknya. Model pembelajaran ini kemudian dikolaborasikan dengan Camtasia Studio yang berfungsi merekam aktifitas desktop atau screen computer yang nantinya bisa dilihat oleh siswa untuk memperdalam penguasaan materi yang disampaikan oleh guru.

Camtasia Studio merupakan perangkat lunak atau sofware yang dikembangkan oleh TechSmith Coorporation khusus bidang multimedia. 
Camtasia Studio adalah program aplikasi yang dikemas dan dikembangkan menjadi lebih menarik untuk recording, editing, dan publishing dalam membuat video presentasi yang ada pada layar screen komputer. Selain itu, Camtasia Studio dapat membantu dan melatih dalam penyajian serta berinteraksi dengan audiens. "Camtasia Studio memiliki kemampuan untuk merekam sesuatu yang ada dalam layar, termasuk kegiatan di desktop, persentasi PowerPoint, narasi suara, dan webcam video" (Widiarto, 2011: 1).

Pada akhirnya melalui model Think-Pair-Share yang dikolaborasi dengan Camtasia Studio, penguasaan akademis siswa terhadap pelajaran TIK materi kompetensi dasar membuat dokumen pengolah angka sederhana dapat meningkat dan pada akhirnya dapat meningkatkan hasil belajar siswa. Model ini diterapkan agar dapat membantu guru dalam meningkatkan hasil belajar siswanya dan diharapkan siswa tidak lagi bosan dan jenuh dengan materi pelajaran TIK. Berdasarkan uraian di atas, peneliti terdorong untuk mengadakan penelitian dengan judul "Peningkatan Hasil Belajar TIK Melalui Model Think-Pair-Share dengan Camtasia Studio Pada Siswa".

\section{B. Metode}

Metode yang digunakan dalam penelitian ini adalah metode penelitian tindakan kelas (classroom action research) menurut Mc Taggart, $\mathrm{R}$ dan Kemmis, S yang terdiri dari 4 tahap, yaitu perencanaan (plan), Pelaksanaan Tindakan (action), observasi (Observation) dan refleksi (reflection). Prosedur yang dilaksanakan dalam penelitian tindakan kelas ini berbentuk siklus yang berlangsung dua siklus. Masing-masing siklus membutuhkan alokasi waktu 2 kali pertemuan atau tatap muka di kelas.

Pada Sikus 1, peneliti bersama mitra kolaborasi menyusun Rencana Pelaksanaan Pembelajaran dengan model pembelajaran ThinkPair-Share dengan Camtasia Studio yang akan diterapkan dalam pembelajaran TIK pada kompetensi dasar membuat dokumen pengolah 
angka sederhana materi pengeditan kolom dan baris, penyisipan objek dan format angka. Pada tiap siklus peneliti menyiapkan Lembar Kerja Siswa (LKS) dan soal tes untuk mengetahui hasil belajar siswa.

Pada tahap pelaksanaan, kegiatan pembelajaran dilaksanakan di laboratorium komputer. Guru membuka pelajaran, kemudian mengulas materi pengeditan kolom dan baris, menyisipkan objek dan format angka dengan mencontohkan cara mengerjakan LKS dengan ditampilkan dengan LCD projektor, kemudian guru menjelaskan skenario pembelajaran yang akan menerapkan model pembelajaran Think-PairShare dengan Camtasia Studio, menginformasikan video tutorial hasil rekaman Camtasia Studio sudah didistribusikan pada folder tiap-tiap komputer yang digunakan untuk praktikum siswa.

Selanjutnya guru membagikan LKS kepada siswa, kemudian memberikan kesempatan kepada siswa untuk memikirkan (think) jawaban dari LKS tersebut secara individu. Tahap selanjutnya siswa diminta berpasangan (pair) dengan teman sebangku. Pasangan teman sebangku sudah didesain atau ditentukan sebelumnya, yaitu berdasarkan hasil tes pada prasiklus dan memperhatikan pemerataan jenis kelamin. Pasangan kelompok diminta untuk saling berdiskusi tentang jawaban LKS yang tepat atas tugas tersebut dan apabila kesulitan dapat membuka rekaman video dari Camtasia. Pada pertemuan selanjutnya beberapa pasangan kelompok untuk berbagi (share) ke depan kelas dengan mempresentasikan jawaban LKS hasil diskusi kelompoknya, kelompok lain menanggapi, dan memberikan penguatan. Selanjutnya guru memberikan kesimpulan dari materi yang sudah dipelajari, pada tahap akhir siswa mengerjakan soal tes secara individu.

Pengamatan dilakukan oleh mitra kolaborasi difokuskan pada kegiatan inti yang dilakukan sesuai Rencana Pelaksanaan Pembelajaran (RPP) yang telah dibuat. Semua temuan dalam pembelajaran dicatat sebagai bahan pertimbangan untuk perencanaan siklus berikutnya. Dari hasil yang diperoleh dari penelitian Siklus 1 sudah menunjukkan 
peningkatan, yakni siswa merasa tertarik dengan model Think Pair Share yang dilaksanakan guru, mulai senang untuk berkontribusi membela kelompoknya, siswa aktif berpartisipasi dalam menjawab pertanyaan yang diajukan, maupun yang rebutan, hasil belajar meningkat ditandai dengan hasil tes yang jauh lebih baik.

Pada tahap refleksi dilakukan analisis tentang keberhasilan tindakan terhadap hasil belajar siswa dari tes kemampuan awal sampai pada berakhirnya kegiatan belajar siklus 1. Pada dasarnya hasil belajar siswa mengalami peningkatan dari kondisi awal (tes prasiklus) sampai dengan siklus 1 . Refleksi dilakukan setelah pembelajaran selesai dan data yang terekam berupa hasil tes individu diambil kesimpulan untuk membuat rencana pelaksanaan siklus berikutnya. Pada akhir tahap penelitian, didapatkan hasil akhir siklus yang telah dianalisis untuk mengetahui tingkat keberhasilan tindakan kelas yaitu ada atau tidaknya peningkatan hasil belajar siswa pada materi yang diajarkan.

Pada siklus 2 diadakan penyempurnaan langkah-langkah pembelajaran sesuai RPP yang dirancang berdasar observasi pada siklus 1, materi untuk siklus 2 adalah rumus dan fungsi, pengaturan halaman dan mencetak dokumen. Pembelajaran siklus 2 tetap dilaksanakan di lab komputer. Pada siklus 2 guru tidak dominan lagi, hanya sesekali berkeliling mengecek hasil LKS siswa di komputernya. Tahap pelaksanaan siklus 2 sudah berjalan dengan baik, kelompok bekerja dengan kompak, saat sharing dengan presentasi sudah berjalan lancar. Di akhir pembelajaran siklus 2 dilaksanakan tes siklus 2 untuk mengetahui peningkatan hasil belajar siswa.

\section{Hasil dan Pembahasan}

\section{Hasil}

Hasil akhir dari tindakan kelas ini adalah meningkatnya hasil belajar siswa yang terlihat dari data hasil kegiatan siswa dalam pembelajaran TIK pada kompetensi dasar membuat dokumen pengolah 
angka sederhana melalui model Think Pair Share dengan Camtasia Studio. Peningkatan hasil belajar siswa tersebut dapat dijabarkan dalam pembahasan berikut ini.

Dari hasil tes siklus 1 pada materi indikator pengeditan kolom dan baris, penyisipan objek dan format angka, hingga tes individu pada siklus 2 pada materi indikator rumus dan fungsi, pengaturan halaman dan mencetak dokumen, memperlihatkan peningkatan hasil belajar siswa di kelas VIII A SMP Negeri 3 Dongko. Peningkatan tersebut dapat diketahui dalam tabel berikut.

Tabel 1. Peningkatan Hasil Belajar TIK Siswa Kelas VIII A

\begin{tabular}{|c|l|c|c|c|}
\hline NO & \multirow{2}{*}{ KRITERIA } & PRA SIKLUS & SIKLUS 1 & SIKLUS 2 \\
\hline \multirow{2}{*}{1} & \multirow{2}{*}{ Tuntas } & 12 Siswa & 18 Siswa & 23 Siswa \\
\cline { 3 - 5 } & & $52,17 \%$ & $78,26 \%$ & $100 \%$ \\
\hline \multirow{2}{*}{2} & \multirow{2}{*}{ Belum Tuntas } & 11 Siswa & 5 Siswa & 0 Siswa \\
\cline { 3 - 5 } & & $47,83 \%$ & $21,74 \%$ & $0 \%$ \\
\hline 3 & Rata-rata & 74,78 & 83,91 & 89,35 \\
\hline
\end{tabular}

Dari tabel di atas terlihat peningkatan rata-rata ketuntasan hasil belajar siswa yang menunjukkan peningkatan, pada prasiklus sebesar 74,78 meningkat pada siklus 1 sebesar 83,91 atau terjadi peningkatan 9,13. Meningkat lagi pada siklus 2 menjadi sebesar 89,35 atau terjadi peningkatan 5,44. Sedangkan prosentase ketuntasan klasikal meningkat dari $52,17 \%$ pada prasiklus, menjadi $78,26 \%$ pada siklus 1 kemudian meningkat lagi menjadi $100 \%$ pada siklus 2 . Apabila dikonversikan pada grafik perbandingan tergambar sebagai berikut. 


\section{Wardoyo}

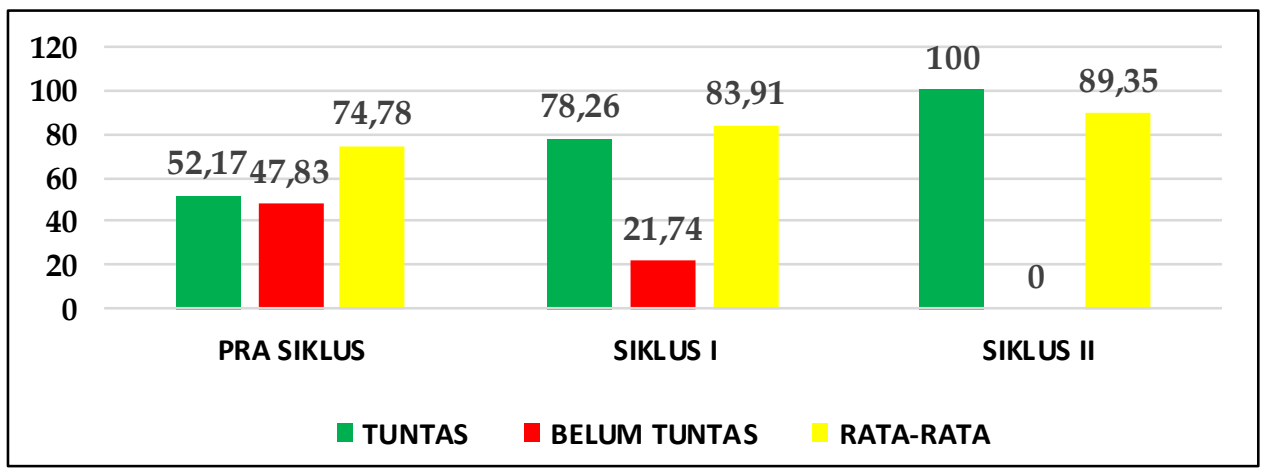

Grafik 1. Peningkatan Hasil Belajar TIK Siswa Kelas VIII A

Dari grafik di atas terlihat perkembangan nyata dari prasiklus, siklus 1 hingga siklus 2, rentang prosentase belum tuntas (warna merah) prasiklus sebesar $47,83 \%$, berkurang siklus 1 sebesar $21,74 \%$ berkurang lagi sebesar $0 \%$ pada siklus 2. Sedangkan prosentase nilai tuntas (warna hijau) prasiklus 52,17\%, siklus 1 meningkat sebesar 78,26\% meningkat lagi menjadi 100\% pada siklus 2. Rata-rata nilai siswa kelas VIII A (warna kuning) prasiklus 74,78 siklus 1 sebesar 83,91 meningkat menjadi 89,35 pada siklus 2 .

Hasil tersebut sudah melebihi target yang direncanakan dalam penelitian tindakan kelas ini yaitu: batas nilai tuntas 75 (Kriteria Ketuntasan Minimal = 75) dan ketuntasan kelas sebesar $85 \%$. Berdasarkan grafik di atas dapat dilihat bahwa target yang ditetapkan telah tercapai, karena pada hasil tes siklus 2 ketuntasan kelas mencapai 100\% dan target yang ditetapkan sebesar $85 \%$. Peneliti bersama kolaborator memutuskan bahwa penelitian tindakan kelas VIII A di SMP Negeri 3 Dongko melalui model Think-PairShare dengan Camtasia Studio dapat meningkatkan hasil belajar TIK pada Kompetensi dasar membuat dokumen pengolah angka sederhana.

\section{Pembahasan}

Penerapan model pembelajaran Think Pair Share dengan Camtasia Studio memberikan dampak positif dalam pembelajaran TIK, siswa lebih proaktif dalam mengerjakan LKS, sehingga pembelajaran tidak terpusat lagi pada guru. Pembelajaran Think Pair Share memberikan kebebasan 
berfikir dan bekerja sama melalui kelompok teman sebangku untuk menyelesaikan LKS yang diberikan guru. Melalui video tutorial dari aplikasi camtasia studio yang sudah di distribusikan dalam folder komputer yang digunakan praktikum siswa, siswa tidak lagi bertanya tentang LKS yang belum dimengerti, sebab siswa akan melihat video tutorial jika lupa penjelasan guru. Siswa lebih mandiri dalam bekerja, tidak lagi tergantung dengan guru. Hal ini senada dengan penelitian yang dilakukan oleh (Januartini et al., 2016) yang menunjukkan bahwa dengan penerapan model Think Pair Share dapat meningkatkan motivasi dan hasil belajar siswa mata pelajaran TIK.

Berdasarkan analisis data hasil belajar melalui tes tulis individu yang dilakukan pada akhir siklus 1 dan siklus 2, dapat disimpulkan bahwa melalui model pembelajaran Think Pair Share dengan Camtasia Studio dapat meningkatkan hasil belajar TIK, khususnya pada materi kompetensi dasar membuat dokumen pengolah angka sederhana, serta dapat mendorong kemandirian siswa dalam mengerjakan LKS. Hal ini selaras dengan penelitian yang dilakukan Arham (2016) yang menunjukkan bahwa dengan menggunakan media pembelajaran berbasis Camtasia Studio dapat meningkatkan hasil belajar siswa kelas XI IPA, sebab Camtasia Studio adalah media yang efektif dan memberikan pengalaman siswa untuk belajar secara mandiri.

\section{Penutup}

Penerapan model Think-Pair-Share dengan Camtasia Studio bias dipsimpulkan dapat meningkatkan hasil belajar mata pelajaran TIK pada kompetensi dasar membuat dokumen pengolah angka sederhana pada siswa kelas VIII A SMP Negeri 3 Dongko. Hal ini dapat ditunjukkan pada peningkatan hasil belajar siswa dari sebelum dilaksanakan tindakan, siklus 1, dan siklus 2. Sebelum pelaksanaan tindakan, ketuntasan hasil belajar siswa yaitu sebanyak 12 siswa tuntas dengan persentase sebesar $52,17 \%$ dan rata-rata kelas sebesar 74,78. Siklus 1 ketuntasan hasil belajar siswa meningkat menjadi 18 siswa dengan persentase sebesar $78,26 \%$ rata- 
rata kelas meningkat menjadi 83,91. Siklus 2 meningkat lagi semua siswa tuntas dengan persentase $100 \%$ rata-rata kelas meningkat lagi menjadi 89,35 . Angka ini melebihi indikator keberhasilan yang telah ditetapkan yaitu ketuntasan kelas sebesar $85 \%$, sehingga dapat disimpulkan bahwa target ketuntasan hasil belajar siswa sebesar 85\% telah tercapai pada siklus 2. Berdasarkan penelitian tindakan yang telah dilaksanakan pada kelas VIII A dapat disimpulkan bahwa dengan penerapan model Think Pair Share dengan Camtasia Studio dapat meningkatkan hasil belajar mata pelajaran TIK materi kompetensi dasar pengoperasian perangkat lunak pengolah angka sederhana.

\section{Ucapan Terima Kasih}

Terima kasih disampaikan kepada Bapak Kepala Dinas Pendidikan, Pemuda dan Olahraga, Bapak Ibu Pengawas dan Tim penilai angka kredit guru yang telah menyelenggarakan workshop penulisan karya tulis ilmiah. Bapak Kepala SMP Negeri 3 Dongko yang telah memberikan ijin dan memfasilitasi penelitian di kelas VIII A, juga Bapak Ibu Guru dalam forum Musyawarah Guru Mata Pelajaran (MGMP) TIK Kabupaten Trenggalek yang telah memberikan dorongan, juga kepada rekan-rekan guru SMP Negeri 3 Dongko yang telah membantu dan berkolaborasi dalam penelitian ini.

\section{Daftar Referensi}

Arends, Richard I, (1997). Learning To Teach: Fifth Edition. Boston: Mc Graw-Hill Companies, Inc.

Arham, M. Al. (2016). Perbandingan Penggunaan Media Berbasis Camtasia Studio Dan Media Powerpoint Terhadap Hasil Belajar Peserta Didik Pada Pokok Bahasan Sistem Pencernaan Kelas XI SMA Negeri 8 Makassar.

Huda, Miftahul. (2011). Cooperative Learning: Metode, Teknik, Struktur, dan Model Penerapan. Yogyakarta: Pustaka Pelajar.

Januartini, P. D., Agustini, K., \& Sindu, I. G. P. (2016). Studi Komparatif Model Pembelajaran Think Pair Square Dan Think Pair Share 
Terhadap Motivasi Dan Hasil Belajar Siswa Mapel Tik Kelas X Sma N 1 Sukasada. Jurnal Pendidikan Teknologi Dan Kejuruan, 13(2), 148 160. https://doi.org/10.23887/jptk.v13i2.8523.

Sudjana, Nana dan Ahmad Rivai. (2009). Media Pengajaran. Bandung: Sinar Baru Algensindo Offset.

Widiarto Sonny. (2011). Membuat Video Tutorial dengan Camtasia Studio 7, http://staff.unila.ac.id/sonnywidiarto/files/2011/11/MembuatVideo-Tutorial-dengan-Camtasia-Studio-7.pdf, diunduh di Trenggalek, 12 Februari 2018. 